Pustaka Karya: Jurnal Ilmiah Ilmu Perpustakaan dan Informasi Vol. 8 No. 2, Desember 2020, Hal. 53-62

http://dx.doi.org/10.18592/pk.v8i2.5130

ISSN (p) : 2089-5216 | ISSN (e) : 2723-7699

\title{
Peran pustakawan dalam menyiapkan generasi emas: implementasi literasi informasi di SD Muhammadiyah Sapen Yogyakarta
}

${ }^{1}$ Anna Nurhayati

${ }^{1}$ Pustakawan SD Muhammadiyah Sapen, Yogyakarta

${ }^{1} \mathrm{Jl}$. Bimokurdo No.33 Yogyakarta, 55281

Email: ${ }^{1}$ annanurhayatisapen@gmail.com

\begin{abstract}
The golden generation is a generation that is able to compete globally with comprehensive intelligence, including productive, innovative, peaceful in social interactions, healthy and healthy in natural interactions, and superior civilization. This type of research is qualitative. Data were collected by in-depth interviews and direct observation. The validity of the data was tested through data triangulation. The data is discussed with the big6 model of information literacy theory. Data analysis using library research method or literature study. Information literacy is the ability to recognize information needs and when information is needed, identify and locate information, evaluate information critically. Information literacy is one way to form a golden generation in the school environment. The big6 literacy model has 6 effective steps that can be used to solve problems, namely; task definition; information seeking strategies; location and access; use the information; synthesis; and evaluation. Implementation of this model requires planning methods and instructor competence. Implementation of information literacy at SD Muhammadiyah Sapen Yogyakarta in the form of library research that produces student work in the form of mini books.
\end{abstract}

Keywords: big6; golden age; information literacy; library research; school library

\begin{abstract}
ABSTRAK
Generasi emas merupakan generasi yang mampu bersaing secara global dengan bermodalkan kecerdasan yang komprehensif antara lain produktif, inovatif, damai dalam interaksi sosialnya, sehat dan menyehatkan dalam interaksi alamnya, dan berperadaban unggul. Penelitian berjenis kualitatif. Data dikumpulkan dengan metode wawancara mendalam dan observasi secara langsung. Data diuji keabsahannya melalui triangulasi data. Data dibahas dengan teori literasi informasi model big6. Analisis data menggunakan metode library research atau studi pustaka. Literasi Informasi merupakan kemampuan untuk menyadari kebutuhan informasi dan kapan informasi tersebut dibutuhkan, mengidentifikasi dan menemukan lokasi informasi, mengevaluasi informasi secara kritis. Literasi informasi merupakan salah satu cara membentuk generasi emas di lingkungan sekolah. Model literasi big6 memiliki 6 buah langkah efektif yang bisa digunakan untuk menyelesaikan masalah yaitu; definisi tugas; strategi mencari informasi; lokasi dan akses; menggunakan informasi; sintesis; dan evaluasi. Pelaksanakaan model ini diperlukan perencanaan metode dan kompetensi instruktur. Implementasi literasi informasi di SD Muhammadiyah Sapen Yogyakarta dalam bentuk library research yang menghasilkan karya siswa berupa buku mini.
\end{abstract}

Kata kunci: Big6; generasi emas; literasi informasi; perpustakaan riset; perpustakaan sekolah

\section{PENDAHULUAN}

Bangsa Indonesia menuju masa kebangkitan. Setelah melewati masa kebangkitan pertama yaitu 50 tahun sejak Indonesia tahun 1945. Kini Indonesia bersiap menghadapai masa pembangunan dengan mempersiapkan generasi emas tahun 2045. Tentu harapan besar masa kebangkitan ini untuk kejayaan Bangsa Indonesia. Masa kebangkitan kedua akan dapat kita rasakan maksimal, manakala persiapan yang maksimal. Dalam sebuah pemberitaan yang dimuat dalam surat kabar 
nasional mengatakan bahwa pencanangan generasi emas tahun pertama juga telah dibarengi dengan revitalisasi pendidikan karakter. Mengintegrasikan (kembali) pendidikan dan kebudayaan merupakan langkah sangat tepat, dengan harapan pendidikan akan melahirkan anak yang berbudaya sehingga jika disatukan akan serasi antara proses dan produk. Sekolah sebagai institusi pendidikan dijadikan sebagai transformasi seorang anak untuk menjadi dewasa yang mampu menghasilkan pengetahuan dan budaya baru. Namun budaya hendaknya tidak serta merta dimaknai secara sempit, tetapi lebih luas lagi, seperti budaya sopan santun, budaya pemanfaatan teknologi. Pemanfaatan teknologi khususnya teknologi informasi dapat kita manfaatkan dengan bijaksana.

Hampir setiap hari kita mendengar dan memanfaatkan informasi. Untuk memenuhi kebutuhan, setiap orang membutuhkan informasi. Informasi memiliki nilai untuk menunjang kehidupan seseorang. Dapat dibayangkan jika manusia hidup tanpa informasi, maka akan mengalami kekerdilan fikiran. Informasi menjadi sangat bernilai tinggi ketika sesuai dengan kebutuhan pencari informasi. Untuk menunjang profesinya, seorang dokter memiliki perbedaan kebutuhan informasi dengan seorang guru maupun petani.

Menurut Naibaho (Naibaho, 2007), jenis informasi sangat mempengaruhi persepsi dan tingkah seseorang. Kesalahan persepsi dan mengambil keputusan dalam bertindak ini berasal dari rendahnya kekuatan berfikir kritis dan analisis informasi yang diterima. Untuk mengatasi semua ini dibutuhkan ketrampilan berinformasi yang lebih dikenal dengan literasi informasi. Dunia pendidikan Indonesia ditantang untuk mendidik siswa yang unggul dalam abad ke-21 serta kompetitif di dunia kerja. Keterampilan literasi informasi memungkinkan pemecahan masalah, berpikir kritis dan kreatif dalam pengambilan keputusan, yang mempersiapkan siswa untuk menghadapi tantangan di masyarakat.

Berkaitan dengan cita-cita membentuk generasi emas, sekolah sebagai tempat untuk menempa siswa menjadi pribadi unggul dan berwawasan global harus menyediakan sumber daya manusia (SDM) yang berkompeten. Guru merupakan tenaga pendidik professional yang paling utama dengan tugas utama mendidik, membimbing, mengarahkan, melatih, menilai, dan mengevaluasi peserta didik. Selain itu, tenaga kependidikan terasuk didalamnya pustakawan dituntut untuk saling bersinergi dalam rangka mewujudkan cita-cita generasi emas di lingkungan sekolah.

Pustakawan sebagai bagian integral dari komunitas sekolah, selayaknya aktif memberikan layanan berkaitan dengan program pembelajaran. Pustakawan seharusnya mampu menciptakan berbagai program pemberdayaan yang bersifat transformasional, dengan melibatkan program perpustakaan dalam pembelajaran termasuk literasi informasi, literasi media, pembinaan minat baca. Tulisan ini akan membahas mengenai generasi emas; konsep literasi informasi di sekolah sebagai salah satu cara pembelajaran untuk membetuk generasi emas; implementasi literasi informasi di SD Muhammadiyah Sapen sebgai salah satu peran pustakawan dalam membentuk generasi emas.

\section{TINJAUAN PUSTAKA}

\section{A. GENERASI EMAS}

Generasi emas mulai didengungkan tahun 2012, tepatnya pada saat peringatan Hari Pendidikan Nasional. Dalam pidatonya Mendikbud, M.Nuh, menyampaikan generasi emas sendiri merupakan generasi yang mampu bersaing secara global dengan bermodalkan kecerdasan yang komprehensif antara lain produktif, inovatif, damai dalam interaksi sosialnya, sehat dan menyehatkan dalam interaksi alamnya, dan berperadaban unggul. Hal ini merupakan harapan terbesar bangsa Indonesia di tahun 2045 nanti. Dengan kata lain generasi emas menjadi sebuah cita-cita luhur bangsa 
Indonesia untuk lebih bermartabat dihadapan bangsa lain di dunia ini. Yang menjadi pertanyaan siapakah yang tergolong dalam generasi emas tersebut.

Menurut Riyono dalam artikelnya bahwa sejak tahun 2010 sampai 2035 Indonesia mendapatkan bonus demografi, yakni populasi usia produktif paling besar sepanjang sejarah Indonesia berdiri. Diperkirakan pada saat HUT Emas 2045 penduduk Indonesia akan mendekati setengah milyar, dan sekitar 100 juta tergolong dalam usia produktif. Berbagai sumber menyebukan, berdasarkan data Badan Pusat Statistik 2011, jumlah penduduk Indonesia 2010 usia muda lebih banyak dibandingkan dengan usia tua. Dalam data itu terlihat, jumlah anak kelompok usia 0-9 tahun sebanyak 45,93 juta, sedangkan anak usia 10-19 tahun berjumlah 43,55 juta jiwa. Nanti pada 2045, mereka yang usia 0-9 tahun akan berusia 35-45 tahun, sedangkan yang usia 10-20 tahun berusia 45-54. Melihat data tersebut dapat disimpulkan bahwa saat ini mereka sedang duduk di bangku pendidikan, baik pendidikan usia dini, dasar hingga perguruan tinggi.

Pendidikan merupakan sebuah proses pembelajaran sepanjang hayat untuk membentuk manusia yang tidak hanya cerdas secara intelektual, mampu mengembangkan potensi spiritualnya. Sekolah sebagai institusi pendidikan dijadikan bukan sebagai transformasi seorang anak untuk menjadi dewasa tetapi malah dijadikan ujung tombak serta seolah-olah pembangunan karakter para penerus bangsa menjadi tugas utama mereka. Guru sebagai tenaga pendidik harus siap menerima tantangan dunia pendidikan di era informasi saat ini. Peran serta tenaga kependidikan termasuk didalamnya pustakawan dituntut bersinergi dengan guru untuk lebih kreatif, inovatif dalam merencanakan kegiatan pembelajaran yang berkualitas untuk menyongsong generasi emas Indonesia.

Pustakawan seharusnya mampu menciptakan berbagai program pemberdayaandengan keterlibatan perpustakaan dalam pembelajaran bersama guru termasuk literasi informasi. Standar AASL (Standards For The 21st Century Leaerners AASL 2007 - Google Search, n.d.), Standars For The $21^{\text {st }}$ Century Leaerners menyebutkan aspek-aspek literasi diselenggarakan dengan tujuan agar siswa mampu untuk: berfikir kritis dalam mendapatkan pengetahuan; menarik kesimpulan, membuat keputusan, menerapkan pengetahuan pada situasi baru serta menciptakan pengetahuan baru; berbagi pengetahuan dan berpartisipasi secara etis dan produktif sebagai anggota masyarakat demokratis; mampu mengembangkan potensi diri dan seni. Dengan demikian sangat mungkin citacita generasi emas akan tercapai. Generasi akan daya saing tinggi berperan secara global bermodalkan kecerdasan dan berbudaya unggul.

\section{B. KONSEP LITERASI INFORMASI}

Beberapa referensi menyebutkan bahwa secara sederhana pengertian literasi informasi merupakan kemampuan untuk menemukan dan menggunakan informasi. Menurut Oberg (Oberg, 2001), literasi informasi perlu memahami arti informasi, dimana informasi sebagai sesuatu yang dibuat, diorganisir dan dibagi, yang mampu mempengaruhi dan dipengaruhi oleh manusia. Permasalahannya informasi sering ditafisirkan sempit, hanya berhubungan dengan promosi dan membaca oleh sebagian perpustakaan. Seharusnya informasi mencakup eksplorasi semua media informasi seperti buku, siaran berita televisi, ensiklopedi.

Literasi Informasi merupakan kemampuan untuk menyadari kebutuhan informasi dan kapan informasi tersebut dibutuhkan, mengidentifikasi dan menemukan lokasi informasi, mengevaluasi informasi secara kritis. Selanjutnya hasil evaluasi ini diorganisasi dan diintegrasikan ke dalam pengetahuan yang sudah ada, memanfaatkan serta mengkomunikasikannya secara efektif, legal dan etis. (Perpustakaan Nasional (Indonesia) \& Indonesia, 2011). 
Dari beberapa pengertian ini dapat disimpulkan bahwa literasi informasi adalah kesadaran kapan kita membutuhkan informasi, mengidentifikasi, menemukan mengevaluasi, mengorganisasi hingga mengintregasikan ke dalam pengetahuan yang sudah ada. Literasi informasi bukan sekedar kemampuan menemukan, namun hal terpenting tumbuh kesadaran kapan informasi itu dibutuhkan untuk mengambil keputusan. Kesadaran ini yang akan menjadi budaya literasi informasi di masyarakat.

\section{TUJUAN LITERASI INFORMASI}

UNESCO dalam Horton (Horton, 2007) menerangkan media dan literasi informasi berperan dalam kehidupan kita sehari-hari. Kebebasan berekspresi merupakan wujud dari pemberdayaan masyarakat untuk memahami fungsi literasi dan media informasi. Tujuan lain dari literasi informasi ini mampu mengevaluasi isi informasi secara kritis, membuat keputusan dan menciptakan informasi, sehingga tercapai kebutuhan baik pribadi, sosial, pekerjaan dan pendidikan.

Tujuan literasi terkait dunia pendidikan, National Forum on Information Literacy (NFIL), sebuah komunitas yang dibentuk untuk mempromosikan literasi informasi secara global menjelaskan, literasi informasi dapat diajarkan dengan cara menunjukkan siswa bagaimana merumuskan pertanyaan penelitian, rencana penelitian sebagai langkah awal pembahasan permasalahan, dengan mengoptimalkan penelusuran. Kita bisa mengajari mereka bagaimana untuk mengevaluasi sumber daya dan menggunakannya secara efektif dan etis. Konsep belajar sepanjang hayat dan berbasis sumber daya menjadi fokus utama NFIL. Dengan demikian memperkuat pemahaman bahwa literasi informasi mampu peningkatan kualitas hidup siswa. Literasi Informasi harus menjadi bagian integral dari pendidikan yang dapat memberikan kontribusi secara kritis terhadap pencapaian tujuan pembangunan.

\section{MODEL LITERASI INFORMASI}

Literasi Informasi merupakan kemampuan untuk menyadari kebutuhan informasi dan kapan informasi tersebut dibutuhkan, mengidentifikasi dan menemukan lokasi informasi. Untuk mendukung kegiatan literasi informasi diperlukan acuan yang sering disebut dengan model literasi informasi. Ada beberapa model yang dapat digunakan untuk mendukung penelitian atau informasi problem solving. Dalam Information Literacy Models and Comparison Chart, terdapat model literasi yang digunakan di Amerika antara lain: The Big6, Information Search Process, Stripling and Pitts Research Process Model, Pathways to Knowledge Information Skills Model.

Dari beberapa model literasi informasi diatas, penulis akan memperdalam lebih lanjut mengenai model Big6. Model literasi informasi Big6 telah banyak digunakan dalam menerapkan informasi untuk memecahkan permasalahan dan pengambilan keputusan. Selain sebagai sebuah proses, Big6 sebagai fondasi dasar dalam life skill. Keterampilan ini dapat diterapkan di sekolah, pengaturan pribadi, dan dunia bekerja. Di sekolah, keterampilan Big6 berlaku untuk semua mata pelajaran di berbagai tingkat kelas. Siswa dapat menggunakan keterampilan Big6 setiap kali mereka membutuhkan informasi untuk memecahkan masalah, membuat keputusan, atau menyelesaikan tugas dari guru mereka yang bekerja sama dengan pustakawan.

Dapat dibayangkan jika setiap perpustakaan sekolah Indonesia menggunakan model literasi seperti ini. Potensi siswa akan terasah sehingga meningkatkan kualitas belajar yang berujung pada peningkatan prestasi siswa. Sesuai dengan namanya, Big6 memiliki 6 buah langkah efektif yang bisa digunakan untuk menyelesaikan masalah yaitu: tugas definisi tugas;strategi mencari informasi; menemukan lokasi dan akses; menggunakan informasi; sintesis; dan evaluasi. 
Terkait dengan peningkatan prestasi siswa, Association of College and Research Libraries (ACRL) dalam Information Literacy Competency Standard For Higher Education (Iannuzzi, 2000) menjelaskan, siswa yang memiliki keterampilan dalam literasi informasi, akan memiliki kemampuan standar sebagai berikut: menentukan batas informasi yang diperlukan; mengakses informasi yang dibutuhkan dengan efektif dan efisien; mengevaluasi informasi dan sumber-sumber informasinya dengan kritis; memadukan sejumlah informasi yang terpilih menjadi dasar pengetahuan seseorang; menggunakan informasi dengan efektif untuk mencapai tujuan tertentu; mengerti masalah ekonomi, hukum, dan sosial sehubungan dengan penggunaan informasi, serta mengakses informasi secara etis dan legal.

\section{METODE}

Penelitian ini mengkaji tentang bagaimana implementasi literasi informasi model big6 bekerja dalam proses belajar mengajar siswa. SD Muhammadiyah Sapen Yogyakarta dipilih sebagai lokasi penelitian karena telah menerapkan model literasi informasi big6 dalam pola pengajarannya. Objek sekunder dalam penelitian ini adalah siswa-siswa SD Muhammadiyah Sapen Yogyakarta sedangkan yang menjadi objek primer ialah kegiatan belajar para siswa terkait dengan literasi informasi.

Pemilihan kedua objek (primer dan sekunder) dilakukan atas dasar untuk memberikan keakuratan data. Dalam bukunya, Nurdin Laugu (Laugu, 2015) menjelaskan agar peneliti memperoleh otoritas yang penuh atas data yang hendak diperoleh, maka objek penelitian harus dibagi mejadi dua yakni objek primer dan objek sekunder. Objek primer yaitu persoalan utama yang diteliti dan objek sekunder yaitu sumber data. Lalu yang berperan sebagai subjeknya ialah peneliti sendiri.

Pengumpulan data dilakukan melalui wawancara mendalam serta observasi langsung. Untuk menguji kevalidan data, digunakan triangulasi data dengan cara mengecek kembali data-data yang didapat melalui wawancara mendalam, mengecek kembali data dari informan melalui teknik yang berbeda dan mengecek kembali informasi yang didapatkan dalam waktu yang berbeda. Analisis data dilakukan dengan metode kualitatif hingga menjadikan penelitian ini berjenis penelitian kualitatif. Lexy J. Modeong menjelaskan penelitian kualitatif adalah suatu penelitian yang menghasilkan data deskriptif berupa kata-kata tertulis atau lisan dari orang dan perilaku yang dapat diamati. (Meleong, 1989)

Untuk membahas data yang didapat, digunakan teori literasi informasi model big6 yang didapatkan dengan metode library research atau studi pustaka dari berbagai sumber-sumber ilmiah seperti buku dan artikel jurnal. Semua hasil analisis data akan ditampilkan dengan menggunakan pendekatan desktriptif.

\section{HASIL DAN PEMBAHASAN}

\section{A. METODE LITERASI INFORMASI DI SEKOLAH}

Dari beberapa model literasi informasi diatas, model yang lazim digunakan di tingkat sekolah khususnya di Indonesia adalah “The Big6”. Model literasi ini dikembangkan oleh Mike Eisenberg dan Bob Berkowitz, dengan pendekatan yang paling banyak dikenal dan digunakan untuk mengajar teknologi informasi dan keterampilan di dunia. The Big6 model ketrampilan informasi untuk pemecahan masalah yang berlaku kapanpun orang membutuhkan dan menggunakan informasi dan cocok untuk segala usia. The Big6 mengintegrasikan pencarian informasi dengan alat-alat teknologi dalam suatu proses yang sistematis, untuk menemukan, menggunakan, menerapkan, dan mengevaluasi informasi. Dengan demikian pemenuhan kebutuhan informasi yang lebih spesifik dan penyelesaian tugas tercapai. Model literasi ini digunakan oleh ribuan sekolah, perguruan tinggi, dan program pelatihan perusahaan. 
Perpustakaan sekolah sebagai bagian dari lembaga pendidikan wajib menerapkan pelatihan literasi informasi. Sejalan dengan pelaksanaan kurikulum 2013 berbasis kompetensi, siswa dituntut dalam kegiatan produktif dan kreatif. Bentuk kegiatan berupa kemampuan dalam menyajikan pengetahuan dalam bahasa yang jelas, logis dan sistematis dalam karya estetis. Kompetensi ini dirancang untuk melalui proses pembelajaran berbasis penemuan (discovery learning) melalui kegiatan berbentuk tugas (project based learning), dan penyelesaian masalah (problem solving based learning), yang mencakup proses mengamati, menanya, menyimpulkan informasi, mengasosiasi dan mengkomunikasikan. (Krisnadi, 2014)

Metode ketrampilan ini menjadi fasilitas bagi di siswa dalam memecahkan permasalahan dalam pembelajaran. Model Big6 menjadi alternatif perpustakaan sekolah dasar dalam memberikan keterampilan literasi siswa. Dalam (Krisnadi, 2014) serta berdasarkan pengalaman penulis menjalankan program literasi informasi, yang tertuang dalam materi "library research, literasi informasi dilakukan dengan urutan:

Pertama, memutuskan dan mengidentifikasi masalah Pada tahap ini dapat dilakukan dengan mengamati dan mendeskripsikan informasi. Setiap siswa mengamati secara teliti salah satu aspek dari topik yang diberikan, misalnya siswa memilih suatu topik anggrek tebu sebagai tumbuhan langka di Indonesia. Selanjutnya siswa mengumpulkan informasi atau fakta yang sesuai dengan tumbuhan langka. Siswa mengumpulkan sedikitnya 15 fakta anggrek tebu dan mendiskripsikan secara lengkap. Semakin lengkap uraian berarti siswa sudah mencapai nalar cukup baik. Langkah selanjutnya mempertanyakan dan menganalisis. Setelah fakta terkumpul, selanjutnya cara ini siswa untuk berfikir kritis untuk mempertanyakan fakta-fakta tersebut. Siswa dapat mempertanyakan: apa yang menyebabkan anggrek tebu menjadi langka; apakah anggrek tebu dapat dikembangkan; bagaimana jika punah. Siswa menganalisis dengan melihat hubungan sebab akibat kelangkaan tumbuhan Indonesia.

Kedua, strategi: mencari sumber daya, memilih dan mengambil informasi. Setelah siswa mengidentifikan masalah, pada tahap ini perencanaan untuk membatasi informasi terhadap sumber-sumber informasi sesuai kebutuhan. Siswa dapat memanfaatkan sumber informasi dengan membaca buku di perpustakaan, wawancara pada narasumber terpercaya, untuk mencari fakta lebih jauh tentang tumbuhan langka.

Ketiga, menemukan: lokasi dan akses informasi. Pada tahap ini siswa menggali informasi dalan sumber informasi dan menemukan sumber dalam sumber. Peran pustakawan sangat dibutuhkan pada tahap ini untuk menggunakan rujukan, antara lain menggunakan ensiklopedi, indeks manual maupun elektronik baik menggunakan OPAC atau mensin pencari yang lain. Pada tahap ini dibutuhkan ketelitian mana informasi yang benar-benar dibutuhkan.

Keempat, menggunakan: mengorganisir dan menyarikan informasi. Setelah informasi terkumpul pada tahap ini siswa harus menyarikan dan menyeleksi informasi untuk permasalahan yang dihadapi. Siswa dapat diajarkan untuk teknik membuat catatan, membaca cepat, membuat mind mapping dalam bentuk summary, kutipan atau paraphrase.

Kelima, sintesis: mengorganisasi berbagai sumber dan presentasi. Tahap ini siswa mengorganisasi sumber yang terpisah menjadi produk yang sistematis untuk mempersiapkan presentasi. Presentasi ini bertujuan untuk menyebarkan informasi yang telah kita dapatkan. Bentuk presentasi dapat berupa power point, cerita atau hasil karya lain berupa buku mini, maket, alat peraga. Pada saat presentasi, siswa harus percaya diri dan mampu mempertahakan pemikiran bilamana ada pertanyaan dari teman yang lain. 
Keenam, evaluasi: evaluasi proses penelitian dan kemajuan kegiatan penelitian. Pada tahap ini siswa diajak untuk menulis secara reflektif antara lain: mengingat kejadian yang telah dilalui siswa selama kegiatan; menuliskan kesan terhadap pengalaman tersebut (puas, senang, gelisah); menuliskan perbaikan rencana yang lebih baik.

\section{B. INSTRUKTUR LITERASI INFORMASI DI SEKOLAH}

Peran pustakawan sebagai pemimpin, memiliki kewenangan untuk mempromosikan semua sumber daya perpustakaan demi kelangsungan pembelajaran. Kemampuan literasi informasi merupakan sebuah life skill yang harus dikembangkan dan dimiliki oleh tenaga pengelola perpustakaan. Salah satu kompetensi pustakawan adalah kompetensi pengelolaan informasi. Di era digilalisasi pustakawan sekolah sebagai ahli informasi, memiliki kewajiban untuk menggerakkan program literasi informasi di sekolah. Shapiro dan Hughes(1996) yang dikutip oleh (Pendit, 2007) mensyaratkan 7 (tujuh) kemampuan yang harus dimiliki pustakawan dalam era digitalisasi.

1) Tool literacy, yaitu kemampuan memahami dan menggunakan alat teknologi informasi, baik secara konseptual maupun praktikal, keterampilan menggunakan perangkat lunak, perangkat keras, multimedia, dan sebagainya; 2) resource literacy, yaitu kemampuan memahami bentuk, format, lokasi, dan cara mendaatkan informasi terutama dari jaringan informasi yang selalu berkembang; 3) social-structural literacy, pemahaman yang benar bagaimana informasi dihasilkan oleh berbagai pihak dalam masyarakat; 4) reserach literacy, kemampuan menggunakan peralatan berbasis teknologi informasi sebagai alat riset; 5) pulishing literacy, kemampuan menerbitkan informasi dan ide ilmiah ke kalangan luas dengan memanfaatkan komputer dan internet; 6) emerging technology literacy, kemampuan terus menerus menyesuikan diri dengan perkembangan teknologi dan bersama komunitasnya menentukan arah pemanfaatan teknologi informasi untuk kepentingan pengembangan ilmu; 7) critical literacy, kemamuan mengevaluasi sercara kritis terhadap untung ruginya menggunakan teknologi telematika dalam kegiatan ilmiah.

\section{IMPLEMENTASI LITERASI INFORMASI DI SD MUHAMMADIYAH SAPEN YOGYAKARTA}

Pembahasan pelaksanaan kegiatan literasi informasi telah dijelaskan berdasakan pengalaman penulis bahwa metode ketrampilan ini menjadi fasilitas bagi di siswa dalam memecahkan permasalahan dalam pembelajaran. Implementasi literasi informasi di SD Muhammadiyah Sapen, yang tertuang dalam materi "library research" yang menghasilkan karya siswa berupa buku mini. Buku mini yang dihasilakn siswa berkaitan dengan tema keindahan negeri Indonesia. Hasil dari kegitan ini diharapkan siswa mampu mengasah daya piker ke tingkat yang lebih tinggi. Rancangan kegiatan ini akan membuka kesempatan siswa untuk bertanya dan menggali informasi yang dekat dengan keseharian siswa. Sebelum memasuki tahapan pembuatan buku mini, siswa dibagi menjadi empat kelompok besar, dengan pembagian:

Kelompok 1: Membahas tentang hewan langka di Indonesia

Kelompok 2: Membahas tentang tumbuhan langka di Indonesia

Kelompok 3: Membahas tentang keindahan alam Indonesia

Kelompok 4: Membahas peninggalan sejarah Indonesia

Langkah pertama: mengamati dan mendiskripsikan. Siswa memilih salah satu topik yang akan dituangkan dalam buku mini, misalnya siswa memilih suatu topik anggrek tebu sebagai tumbuhan langka di Indonesia. Selanjutnya siswa mengumpulkan informasi atau fakta yang sesuai dengan fokus yang telah dipilih dalam hal ini anggrek tebu. Siswa sedikitnya mengumpulkan sedikitnya 
10 fakta dan mendiskripsikan secara lengkap. Guru dan pustakawan dapat mengarahkan kemampuan pengamatan siswa. Semakin lengkap uraian siswa telah mencapai daya nalar.

Langkah kedua: mempertanyakan dan menganalis. Setelah siswa mengumpulkan secara lengkap semua fakta-fakta hasil pengamatan, langkah selanjutnya mempertanyakan tentang fakta tersebut. Misalnya jika diketahui anggrek tebu adalah tumbuhan yang hampir punah, siswa dapat mempertanyakan apa yang menyebabkan anggrek tebu menjadi langka; apakah anggrek tebu dapat dikembangkan; bagaimana jika punah. Siswa menganalisis dengan melihat hubungan sebab akibat kelangkaan tumbuhan Indonesia.

Langkah ketiga: menggali informasi. Setelah mengidentifikasi fakta dan mengkaji lebih jauh siswa perlu menindaklanjuti dengan mengumpulkan informasidengan berbagai cara antara lain: bertanya kepada narasumber terkait dan orangtua atau guru; membaca buku referensi tentang tumbuhan langka Indonesia; membawa gambar-gambar tentang tumbuhan langka dan mendiskusikan tentang keunikan tumbuhan tersebut. Peran pustakawan pada tahap ini sangat membantu dalam mengakses informasi. Bagaimana mencari sumber informasi dengan cepat dan tepat.

Langkah keempat: persiapan pembuatan buku mini. Pada tahap ini lebih ditekankan pada pengamatan gambar dan menggali informasi dari teks. Guru dan pustakawan mengajak siswa untuk mempersiapkan proses buku mini, misalnya persiapan, alat dan bahan, jumlah halaman, struktur buku. Siswa dapat diajak ke perpustakaan untuk menggali informasi dengan cara berdiskusi dalam kelompok dengan bantuan pustakawan tentang persiapan pembuatan buku mini yang menarik dan informatif. Pada tahap ini siswa juga dituntut untuk mempersiapkan bahan presentasi, point-point utama yang akan disampaikan dan peraga pendukung.

Langkah kelima dan keenam: menyampaikan hasil dan melakukan evaluasi. Tahap ini siswa menyampaikan hasil kerja di hadapan teman-teman dan guru. Pada saat presentasi, siswa harus percaya diri dan mampu mempertahakan pemikiran bilamana ada pertanyaan dari teman yang lain. Setelah disampaikan hasil, maka selanjutnya dilakukan evaluasi. Siswa dibiasakan untuk menulis kejadian menarik selama melakukan pembuatan buku mini, seperti kesan pengalaman ( puas, tidak puas, senamg, bingung atau gelisah)

\section{KESIMPULAN}

Literasi informasi memiliki berbagai macam model. Model yang lazim dikembangkan di sekolah adalah the Big6. Model Big6 ini telah banyak digunakan dalam menerapkan informasi untuk memecahkan permasalahan dan pengambilan keputusan. Selain sebagai sebuah proses, Big6 sebagai fondasi dasar dalam life skill. Keterampilan ini dapat diterapkan di sekolah, pengaturan pribadi, dan dunia bekerja. Di sekolah, keterampilan Big6 berlaku untuk semua mata pelajaran di berbagai tingkat kelas. Metode ketrampilan ini menjadi fasiltas bagi siswa dalam memecahkan permasalahan dalam pembelajaran. Model Big6 menjadi alternatif perpustakaan sekolah dalam materi "library research" dengan urutan: memutuskan: mengidentifikasi masalah; strategi: mencari sumber daya, memilih dan mengambil informasi; menemukan: lokasi dan akses informasi; menggunakan: mengorganisir dan menyarikan informasi; sintesis: mengorganisasi berbagai sumber dan presentasi; evaluasi: evaluasi proses penelitian dan kemajuan kegiatan penelitian. Implementasi literasi informasi di SD Muhammadiyah Sapen Yogyakarta dalam bentuk library research yang menghasilkan karya siswa berupa buku mini dengan langkah-langkah: mengamati dan mendiskripsikan; mempertanyakan dan menganalis; menggali informasi; persiapan pembuatan buku mini; menyampaikan hasil; melakukan refleksi/ evaluasi. 


\section{DAFTAR PUSTAKA}

Bachtar, Mulni Adelina.(2009).”Literasi Informasi Tenaga Pendidik Dan Kependidikan Pendidikan Nonformal (PNF) Di Provinsi Dki Jakarta”. BACA, Vol.30, 121-122

Big6 Skills Overview,Diambil tanggal 23 Maret 2015 dari: http://big6.com/pages/about/big6skills-overview.php

Dwiyanto, Arif Rifai (2007). "Peran Perpustakaan Nasional RI dalam Pengembangan Literasi Informasi Sebagai Amanat Konstitusi”. Visi Pustaka, Vol.9

Horton, F. W. (2007). Understanding information literacy: A Primer. UNESCO. http://unesdoc.unesco.org/images/0015/001570/157020e.pd

Iannuzzi, P. (2000). Information Literacy Competency Standards for Higher Education. Community \& Junior College Libraries, 9(4), 63-67. https://doi.org/10.1300/J107v09n04_09

Kompas. (2013) Pendidikan Berkualitas untuk Generasi Emas http://edukasi.kompas.com/read/2013/10/18/1053115/Pendidikan.Berkualitas.untuk.Gener asi.Emas

Krisnadi, I. (2014). Indahnya Negeriku. KEMENDIKBUD. https://pmpk.kemdikbud.go.id/bukudigital/read/pdf/indahnya-negeriku-5fc143ae685b6

Laugu, N. (2015). Representasi Kuasa Dalam Pengelolaan Perpustakaan. Gapernus Press.

Meleong, L. J. (1989). Metologi penelitian kualitatif. PT Remaja Rosdakarya.

Naibaho, K. (2007). Menciptakan Generasi Literat Melalui Perpustakaan. Visi Pustaka, 9(No. 3), 1-8. http://eprints.rclis.org/12549/

Oberg, D. (2001). Editorial: Perspectives on information literacy - ProQuest. School Libraries Worldwide, 7(1). https://www.proquest.com/openview/eb96e8eb127437efe1d22a8838d471aa/1?pqorigsite $=$ gscholar $\&$ cbl $=45830$

Pendit, P. L. (2007). Perpustakaan Digital: Perspektif Perpustakaan Perguruan Tinggi Indonesia. Sagung Seto.

Perpustakaan Nasional (Indonesia), \& Indonesia (Eds.). (2011). Standar nasional perpustakaan (SNP). Perpustakaan Nasional RI.

Parr.K.(2012).“The Impact of school libraries on student achievementand success”. Missisipi Libraries, Vol.75, 18-22

Riyono, Ahdi.” Generasi Emas dan Daya Saing Bangsa”. Diambil tanggal 3 Juni

2015 pukul $14.00 \quad$ dari: http://infomuria.umk.ac.id/index.php?option=com_content\&view=article\&id=1049:gener asi-emas-dan-daya-saing-bangsa\&catid

Standards For The 21st Century Leaerners AASL 2007-Google Search. (n.d.). Retrieved September 24, 2021, from

https://www.google.com/search?q=Standards+For+The+21st+Century+Leaerners+AASL+2007\&rlz=1C1

VDKB_enID954ID954\&sxsrf=AOaemvLtTukCRoS- 
kJP2ITKssl4xtU8LeA\%3A1632448246064\&ei=9i5NYbGqA4qrrgSp-

YmIAw\&oq=Standards+For+The+21st+Century+Leaerners+AASL+2007\&gs_lcp=Cgxnd3Mtd216LXNlc nAQAzIHCAAQRxCwAzIHCAAQRxCwAzIHCAAQRxCwAzIHCAAQRxCwAzIHCAAQRxCwAzIHC AAQRxCwAzIHCAAQRxCwAzIHCAAQRxCwA0oECEEYAFD9WljZYWDoY2gAcAJ4AIABAIgBAJI BAJgBAKABAcgBCMABAQ\&sclient=gws-wiz-

serp\&ved=0ahUKEwix_cfOv5bzAhWKIYsKHal8AjEQ4dUDCA4\&uact=5 